\title{
Competence (Knowledge, Attitudes and Skills) Midwifeve to Handling of Obstetric Emergency According to Standard Operational Procedures
}

Tety Ripursari

Indonesia

Email:

tetty30578ripursari@gmail.com
Received: March 12, 2019

Accepted: October 13, 2019

Published : November 26, 2019

\begin{abstract}
One of the efforts to reduce maternal mortality rate is to improving the quality of service handling obstetric emergency by midwife. The purpose of the research is to analyze the competence (knowledge, attitude and skill) of midwife against the handling of obstetric emergencies in the City of Blitar. The desain used in the research is analytic quantitative. Population are all midwives in Blitar City of 158 people. The sample size is 113 respondents, using simple random sampling tehnique. Independent variable of is knowledge, attitude and sklill, dependent variable is handling of obstetric emergency according to Standard Operational Procedures (SOP). Data collected by questionnaire and observation then analized using logistic regression. Statistical test result obtained that the knowladege variables $p$ value $0,042<\alpha=$ 0,005 , meaning that knowledge have an effect the handling of obstetric emergency, attitude variable $p$ value $0,003<\alpha=0,05$, meaning attitude have an effect on handling of obstetric emergency, skill variable $p$ value $0,038<\alpha=0,05$, meaning skill have an effect on handling of obstetric emergency. The lowest/smallest variable is the attitude variable, where the $\mathrm{p}$ value is $0,003<\alpha=0,05$, meaning that dominant factor that influences the handling of obstetric emergencies according to SOP is the attitude variable. Knowledge, attitudes and skills of midwives affect the handling of obstetric emergencies according to SOP in the City of Blitar.
\end{abstract}

Keywords: Knowledge, attitude, skill, obstetric emergency 


\section{INTRODUCTION}

Maternal Mortality Rate (MMR) in Indonesia is still high. As a benchmark for maternal health success, one of the most important indicators to assess the quality of obstetric and gynecological services in a country is to assess the Maternal Mortality Rate (MMR). One of the causes of the high mortality rate is obstetric emergency is a problem that is often experienced in the field of obstetrics and daily practice. Obstetric emergencies are a sudden, unexpected, life-threatening condition that requires prompt and appropriate treatment to prevent morbidity and mortality. Obstetric emergencies are usually caused by bleeding, eclampsia, infection, prolonged labor due to dystocia and miscarriage. Bleeding is the highest cause of death in obstetric emergencies, namely bleeding (30.3\%), hypertension $(27.1 \%)$, infection (7.3\%), prolonged labor (1.8\%), abortion (1.6\%), and other causes (40.8\%) (Kemenkes RI, 2014).

Obstetric emergency problems in Indonesia occur because of experiencing four things, namely late recognition of danger signs and risks, late decision making to seek help, late getting transportation to reach health care facilities that are more capable, and late getting help in referral facilities. Early recognition and initial management of obstetric emergencies is the key to the success of emergency treatment. With proper early treatment, the rate of maternal and fetal morbidity and mortality can be reduced Emergency is an emergency in pregnant women, childbirth and childbirth. Obstetric emergency cases if not treated immediately will result in maternal and fetal death. Obstetric emergency management can be influenced by factors of knowledge, skills, right and correct decision making, and also experience. Obstetric emergency services require continuity of service and access to emergency obstetric services when complications arise. So that every delivery must be assisted by trained health personnel, improvement of emergency obstetric services when complications arise, as well as an effective referral system. One of the important things that contribute to maternal mortality is the quality of obstetric services at various levels of health services. Reducing maternal mortality and morbidity is one of the maternal and child health programs (Sarma, 2017).

In this case midwives have a very important role in reducing maternal mortality because midwives are recognized as responsible and accountable professionals, who work as female partners to provide support, care and advice during pregnancy, labor and childbirth, leading the birth own responsibility and provide care to the baby born. This care includes prevention, promotion, normal childbirth, detection of complications in the mother and child, access to medical assistance or other appropriate assistance, and carrying out emergency actions. Efforts to accelerate the reduction of MMR can be done by ensuring that every mother is able to access quality maternal health services, such as maternal health services, delivery assistance by trained health workers in every health care facility, postpartum care for mothers and babies, special care and referrals if they occur. Compilation, ease of getting leave and childbirth, family planning services (Kemenkes, 2014).

In Blitar City there are 3 Puskesmas, 5 General Hospitals (RSU) and 2 Mother and Child Hospitals (RSIA) and 20 Independent Midwifery Practices (PBM). From the preliminary observations conducted by researchers in April 2018 it was found that the most emergency cases were former cesarean section, rupture of membranes (KPD), postdate, pre eclampsia, abortion, prolonged labor, breech location, fetal distress, hyperemesis gravidarum, IUFD and post partum hemorrhage. Obstetric emergency cases are referred by midwives to referral facilities such as hospitals.

Researchers see that the handling of obstetric emergencies is still not in accordance with the stipulated. For example in the case of Pre-Eclampsia Weight (PEB) the mother should be infused, dower catheter installed and injected with $\mathrm{MgSo} 4$ (magnesium sulfas) and given oxygen, but most mothers were referred before giving the action, even though the treatment is very important to prevent seizures. (eklamsi). Also in bleeding patients with hypovolemic shock (bleeding shock), most still carry out a single infusion of Intra Vena line so that fluid resuscitation is less fulfilled, and so on. Whereas early treatment of cases will be very meaningful for the mother so that the mother and baby can be saved because the midwife is the first health worker to handle the patient, especially the obstetric emergency case before handling it to the referral place.

Considering the important role of midwives in handling obstetric obstetric care to reduce maternal mortality, researchers will explore how competencies (knowledge, attitudes and skills) of midwives in handling obstetric emergencies according to SOP in Blitar City.

\section{MATERIALS AND METHODS}


This study uses quantitative analytical methods using a cross sectional approach. The population in this study was that all midwives in Blitar City who were members of the IBI branch of Blitar City had 158 midwives. The sample size in the study was 113 respondents using simple random sampling technique. The independent variables in this study are the knowledge, attitudes and skills of the midwife, while the dependent variable is the handling of obstetric emergencies according to SOP. Data were collected using questionnaires and observations, then analyzed using logistic regression test.

\section{RESULT}

\section{Distribution of Respondent Characteristics}

Table 1 Distribution of characteristics of respondents based on age, education, years of service, PPGDON training, MU training, and finally MU training.

\begin{tabular}{clcc}
\hline No. & Age & Frequency & Percentage $(\%)$ \\
\hline 1 & $20-30$ years & 48 & 42,5 \\
2 & $31-40$ years & 40 & 35,4 \\
3 & $>40$ years & 25 & 22,1 \\
\hline \multicolumn{2}{l}{ Total } & 113 & 100,0 \\
\hline
\end{tabular}

Based on the table above it was found that out of 113 respondents almost half of the respondents had 20-30 years old as many as 48 respondents $(42.5 \%)$.

Table 2. Distribution of characteristics of respondents based on education

\begin{tabular}{clcc}
\hline No & Education & Frequency & Percentage $(\%)$ \\
\hline 1 & D III & 76 & 67,3 \\
2 & DIV/S1 & 35 & 31,0 \\
3 & Postgraduate & 2 & 1,8 \\
\hline & Total & 113 & 100,0 \\
\hline
\end{tabular}

Based on the above table it was found that out of 113 respondents almost all respondents had DIII education as many as 76 respondents $(67.3 \%)$.

Table 3. Distribution of characteristics of respondents based on years of service.

\begin{tabular}{clcc}
\hline No & Working Periode & Frequency & Percentage $(\%)$ \\
\hline 1 & $<5$ years & 39 & 34,5 \\
2 & $5-10$ years & 34 & 30,1 \\
3 & $>10$ years & 40 & 35,4 \\
\hline & Total & 113 & 100,0 \\
\hline
\end{tabular}

Based on the table above it was found that from 113 respondents almost half of the respondents had a tenure of more than 10 years as many as 40 respondents (35.4\%).

Table 4. Distribution of characteristics of respondents based on PPGDON training

\begin{tabular}{clcc}
\hline No & PPGDON Training & Frequency & Percentage $(\%)$ \\
\hline 1 & Never & 94 & 83,2 \\
2 & Ever & 19 & 16,8 \\
\hline & Total & 113 & 100,0 \\
\hline
\end{tabular}

Based on the above table it was found that out of 113 respondents almost all respondents had never trained PPGDON as many as 94 respondents $(83.2 \%)$

Table 5. Distribution of characteristics of respondents based on MU training

\begin{tabular}{clcc}
\hline No & MU Training & Frequency & Percentage $(\%)$ \\
\hline 1 & Never & 29 & 25,7 \\
2 & Ever & 84 & 74,3 \\
\hline & Total & 113 & 100,0 \\
\hline
\end{tabular}

Based on the above table it was found that out of 113 respondents almost all respondents had MU training in 84 respondents $(74.3 \%)$. 
Table 6. Distribution of characteristics of respondents based on the last MU training

\begin{tabular}{clcc}
\hline No & Last MU Training & Frequency & Percentage $(\%)$ \\
\hline 1 & Never MU & 29 & 25,7 \\
2 & < 1 year & 33 & 39,3 \\
3 & 1 -3 years & 51 & 60,7 \\
\hline & Total & 113 & 100,0 \\
\hline
\end{tabular}

Based on the table above it was found that from 113 respondents most of the last respondents

MU training 1-3 years as many as 51 respondents $(60.7 \%)$.

\section{Variable Characteristic Distribution}

Table 7. Distribution of variable characteristics based on midwife knowledge in Blitar City.

\begin{tabular}{clcc}
\hline No. & Knowledge & Frequency & Percentage $(\%)$ \\
\hline 1 & Less & 21 & 18,6 \\
2 & Enough & 71 & 62,8 \\
3 & Good & 21 & 18,6 \\
\hline & Total & 113 & 100,0 \\
\hline
\end{tabular}

Based on the above table, it was found that out of 113 respondents, the majority of respondents had enough knowledge as many as 71 respondents $(62.8 \%)$.

Table 8. Distribution of variable characteristics based on the attitude of midwives in Blitar City.

\begin{tabular}{clcc}
\hline No & Attitude & Frequency & Percentage $(\%)$ \\
\hline 1 & Less & 10 & 8,8 \\
2 & Enough & 25 & 22,1 \\
3 & Good & 78 & 69,0 \\
\hline & Total & 113 & 100,0 \\
\hline
\end{tabular}

Based on the above table it was found that out of 113 respondents, almost all respondents had a good attitude as many as 78 respondents (69.0).

Table 9. Distribution of variable characteristics based on midwife skills in Blitar City

\begin{tabular}{clcc}
\hline No & Skill & Frequency & Percentage $(\%)$ \\
\hline 1 & Less & 5 & 4,4 \\
2 & Enough & 63 & 55,8 \\
3 & Good & 45 & 39,8 \\
\hline & Total & 113 & 100,0 \\
\hline
\end{tabular}

Based on the above table, it was found that out of 113 respondents, the majority of respondents had sufficient skills as many as 63 respondents (55.8\%).

Table 10 Distribution of variable characteristics based on the handling of obstetric emergencies according to SOP in the City of Blitar.

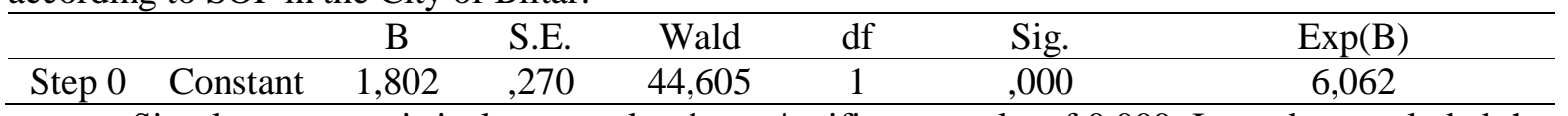

Simultaneous statistical test results show significant results of 0,000 . It can be concluded that all independent variables (knowledge, attitudes and skills) jointly influence the dependent variable (handling obstetric emergencies in Blitar City.

Table 11. Multivariate analysis with partial logistic regression

\section{Variables in the Equation}

\begin{tabular}{llcccccc}
\hline & & B & S.E. & Wald & Df & Sig. & Exp(B) \\
\hline \multirow{3}{*}{ Step $1^{\text {a }}$} & Knowledge & 2,746 & 1,415 & 3,767 & 1 &, 042 & 15,578 \\
\cline { 2 - 8 } & Attitude & 3,699 & 1,266 & 8,536 & 1 &, 003 & 40,391 \\
\cline { 2 - 8 } & Skill & 4,681 & 2,254 & 4,311 & 1 &, 038 & 107,842 \\
\cline { 2 - 8 } & Constant & $-21,603$ & 8,175 & 6,983 & 1 &, 008 &, 000 \\
\hline
\end{tabular}


The results of statistical tests partially showed that the knowledge variable obtained $p$ value of $0.042<\alpha=0.05$, so that $\mathrm{H} 0$ is rejected and $\mathrm{H} 1$ is accepted, meaning that knowledge variables affect the handling of obstetric emergencies according to SOP in Blitar City, attitude variables obtained $\mathrm{p}$ value of $0.003<\alpha=0.05$, so $\mathrm{H} 0$ is rejected and $\mathrm{H} 1$ is accepted, meaning that the attitude variable influences the handling of obstetric emergencies according to SOP in Blitar City, the skill variable is obtained $\mathrm{p}$ value of $0.038<\alpha=0.05$, so $\mathrm{H} 0$ is rejected and $\mathrm{H} 1$ accepted, meaning that the skill variable affects the handling of obstetric emergencies according to the SOP in the City of Blitar.

The value of the lowest $p$ / lowest value is in the attitude variable, where the $p$ value is $0.003<\alpha=0.05$, meaning that the attitude variable is the dominant factor that influences the handling of obstetric emergencies according to SOP in Blitar City.

\section{DISCUSSION}

\section{The Influence of Midwife Knowledge on Handling Obstetric Emergency According to SOP in Blitar City}

Based on the results of the study found that from 113 respondents the majority of respondents in Blitar City had enough knowledge as much as 71 respondents $(62.8 \%)$, respondents were well informed as many as 21 respondents (18.6\%), and respondents with less knowledge were 21 respondents (18, $6 \%$ ). Knowledge is what is known by a person or respondent related to the obstetric emergency case of Notoatmodjo (2014). Sunaryo, 2010) also states that knowledge is the result of knowing that occurs through sensory processes, especially the eyes and ears of certain objects, knowledge is a domain that is very important for the formation of overt behavior.

In the results of the knowledge questionnaire it was found that out of 21 respondents who had less knowledge because there were some who were not filled in / answered, some of them did not answer correctly. The majority of respondents answered incorrectly about the question about blood volume deficits in hypovolemic shock, abruption of the placenta, placenta previa. Knowledge of blood volume deficits in hypovolemic shock, abruption of placenta and placenta previa is very important to know midwives because midwives can determine subsequent treatment and replace lost fluid and blood needs. With good knowledge the handling will be appropriate and appropriate, and can prevent complications that will occur to the mother and baby.

Based on the results of the study, of 113 respondents who were knowledgeable enough to have emergency treatment according to SOP as many as 67 respondents $(59.3 \%)$ and those who did not comply with SOP 4 respondents (5.5\%), respondents who were well-informed all had emergency treatment according to SOP 21 respondents (18.6\%), knowledgeable lacked the handling of emergencies according to the SOP as many as 9 respondents $(8.0 \%)$ and those who did not comply with the SOP 12 respondents $(10.6 \%)$. The results of statistical tests using logistic regression obtained $\mathrm{p}$ value of $0.042<\alpha=0.05$, meaning that knowledge affects the handling of obstetric emergencies according to SOP in Blitar City.

Midwives as the leading health workers often encounter cases of handling obstetric emergencies, so that knowledge of good midwives is needed to determine subsequent actions and treatment. With good knowledge the midwife will be able to handle obstetric emergency cases quickly and accurately. So that complications or unwanted impacts can be prevented as early as possible. Early determination of obstetric emergency cases is very important to be known by midwives as the front guard who is dealing directly with patients. Midwives who have adequate knowledge will be able to provide obstetric emergency assistance according to their authority and are able to do work effectively and efficiently in handling obstetric emergencies according to their knowledge. Cases that are obstetric emergencies that are not the authority of the midwife must be collaborated or collaborate with Sp.OG specialists and related teams for further treatment to save mothers and babies, so that maternal and infant mortality can decrease.

\section{The Influence of Midwives' Attitudes to Handling Obstetric Emergency According to SOPs in Blitar City}

Based on the results of the study, from 113 respondents found that almost all respondents had a good attitude as many as 78 respondents (69\%), enough attitude as many as 25 respondents $(22.1 \%)$, lack of attitude as many as 10 respondents $(8.8 \%)$. 
According to Azwar (2000), attitude (attitude) is a reaction or response that is still closed from someone to a stimulus or object. Attitudes cannot be directly seen, but only interpreted in advance from closed behavior. Attitude is a form of feeling evaluation or reaction. A person's attitude towards an object is a feeling of being supportive or favorable and a feeling that is not supportive of a particular object.

Based on the results of the study it was found that out of 113 respondents almost all respondents with good attitude had obstetric emergency treatment according to the SOP as many as 77 respondents $(68.1 \%)$ and who did not comply with SOP 1 respondent (9\%). Respondents with sufficient attitude had emergency handling in accordance with SOP as many as 20 respondents $(17.7 \%)$ and those who did not comply with SOP 3 respondents $(4.4 \%)$. Respondents with a lack of attitude did not have emergency handling in accordance with SOP and 10 respondents were not compliant $(8.8 \%)$. The results of statistical tests using logistic regression found that the value of $p$ value $0.03<\alpha=0.05$, meaning that the attitude affects the handling of emergencies according to SOP in the City of Blitar.

In the results of the attitude questionnaire, it was found that most respondents were less in the case of top priority conducted by midwives in the area and handling cases of obstetric emergencies. As a midwife, you must have a supportive attitude in handling obstetric emergencies. The attitude of the midwife is very important to decide something before acting in handling obstetric emergency cases to reduce maternal and infant mortality. Because the wrong attitude taken will cause things that could endanger the safety of the mother and her baby. Determination of the main priorities conducted by midwives in the area in an effort to reduce maternal mortality rates, especially in cases of obstetric emergencies, is not a decision to refer but should be an immediate introduction of cases, stabilization and handling of obstetric emergencies before referral is made.

The more often the midwife takes care of obstetric emergencies, the midwife will become more experienced and skilled in handling it so that the attitudes to implementing standards for handling obstetric emergencies according to SOP are better. Not just knowledge, but the attitude of a supportive midwife is needed in providing services to mothers, especially in handling obstetric emergency cases. With a good attitude the midwife can determine what actions will be taken in handling obstetric emergency cases. Decision making to act is very important because if one makes a decision, it will affect the safety of the mother and the baby.

\section{Influence of Midwife Skills on Handling Obstetric Emergency According to SOP in Blitar City}

Based on the results of the study, it was found that out of 113 respondents, the majority of respondents had sufficient skills as many as 63 respondents (55.8\%), 45 respondents had good skills, and 5 respondents had less skills.

According to Hutapea (2008) skills are a person's ability to carry out an activity or work. While Notoatmodjo (2014) said that skills are applications of knowledge, so that the level of one's skills is related to the level of knowledge.

Widayatun (2009) states that the factors that can affect skills are 1). Motivation, is something that arouses a desire in a person to take action, 2). Experience, is a thing that will strengthen a person's ability to do an action (skill) so that subsequent actions become better because they have done actions in their past, 3). Expertise, is something that someone has that will make someone capable and skilled at doing things according to what they have been taught.

Based on the results of the study, it was found that out of 113 respondents, almost half of the respondents with skills had sufficient obstetric emergency treatment according to the SOP of 53 respondents (46.9\%) and those who did not comply with the SOP of 10 respondents. Respondents with good skills had emergency treatment according to SOP as many as 44 respondents (38.9\%) and those who did not comply with SOP 1 respondent. Respondents with less skills did not have emergency treatment according to SOPs and those who did not comply with SOP were 5 respondents $(4.4 \%)$. The results of statistical tests using logistic regression found that the value of $p$ value $0.038<\alpha=0.05$, meaning that the skills affect the handling of emergencies according to SOP in the City of Blitar. Skills are the ability for midwives to carry out obstetric emergency actions.

Skilled and capable midwives will be able to handle obstetric emergencies precisely and quickly to save mothers and babies. As a midwife, not only is required to have knowledge and attitude, but also must have skills, so that she can become a professional midwife in providing services to individuals, 
families and surrounding communities. A midwife in carrying out midwifery practices must be able to help with obstetric emergency cases in accordance with the SOP.

In the results of the research observations it was found that the midwives observed by MU's testing team and the head of the room tended to be somewhat nervous / tense, because the testing team was near the respondent, for example when giving an explanation to the midwife communication patient stammering or repeating, too when doing the infusion the midwife forgot to record the date and time of installation on the infusion, it was also found because she was a little panicked until she dropped the tape, there was also a tremor of her hand when doing infusion or when sewing perineum.

When met at the time of the study, the skills of the midwives who were less in handling preeclampsia cases found that some midwives other than in the hospital handling cases of preeclampsia were still hesitant and confused in administering MgSo4, determining doses and injections were still confused. Some even immediately suggested that the patient go to the hospital before being given $\mathrm{MgSo} 4$ on the grounds that the medicine ran out. Also found in cases of post partum hemorrhage, it was found that patients with a lot of bleeding were only infused with one location, suturing at the site of rips and referred to the hospital, even though such cases should have been inserted 2 locations to meet fluid needs due to blood loss and then referred to the hospital. Also found in cases of prolonged labor, there were cases of prolonged labor in the second stage, after being led not born, the midwife immediately referred the patient to the hospital, the patient was so exhausted after being delivered for 1 hour, the patient should be infused first to improve the condition patient and stabilization and anticipate the occurrence of things that are not desirable, then referred to the hospital for further treatment.

\section{The Influence of Midwife's Knowledge, Attitudes and Skills on Handling Obstetric Emergency According to SOP in Blitar City}

Based on the results of the study it was found that out of 113 respondents almost all respondents had obstetric emergency treatment according to SOP as many as 97 respondents (85.5\%), and 16 respondents had obstetric emergency treatment that was not in accordance with the SOP.

Obstetric emergency management is an action taken by a midwife to handle obstetric emergency cases quickly and accurately to prevent morbidity and mortality. In handling obstetric emergencies requires knowledge, skills, appropriate and correct decision making, and experience (Kemenkes, 2016).

In this study, the handling of obstetric emergencies in accordance with SOP is most often found in respondents who work in hospitals. Frequent midwives in hospitals encounter obstetric emergency cases, making midwives accustomed and skilled in handling obstetric emergencies according to SOPs. Whereas the respondents who did not comply with SOP were more commonly found in respondents who worked in addition to hospitals. The respondent was met as a pediatrician assistant, obstetrician assistant, working online, and did not work. Besides that, because the SOP in each agency and clinic is different from one another, but in general there are similarities in the handling of obstetric emergencies.

Competence (knowledge, attitude and skills) is very important for a midwife. All three are equally important, midwives not only have to have good knowledge, but also midwives must have good attitude and skills as well. Competent midwives will be able to handle obstetric emergencies skillfully, quickly and precisely so that the goal of handling obstetric emergencies to reduce maternal and infant mortality can be achieved.

\section{Dominant Factors Affecting the Management of Obstetric Emergency According to the SOP in the City of Blitar}

In the statistical results it was found that the value of the $\mathrm{p} /$ lowest value in the attitude variable, where the attitude variable $p$ value of $0.003<\alpha=0.05$, which means that attitude is the dominant factor affecting the handling of obstetric emergencies according to SOP in the City of Blitar.

The dominant factor is a factor whose influence is stronger than other factors. The results showed that the attitude of midwives towards the handling of obstetric emergencies in Blitar City was the most influential factor compared to the factors of knowledge and skills of midwives. The attitude of the midwife in Blitar City has a good attitude. Attitude is the variable that most influences the handling of obstetric emergencies in the City of Blitar. Because with an attitude, midwives can make decisions to deal with cases of obstetric emergencies in the city of Blitar. With good attitude, the midwife will be 
able to handle obstetric emergency cases appropriately and quickly so that they will avoid undesirable things so that maternal and infant mortality will be prevented or can be reduced

\section{CONCLUSION}

From the results of the study, it was found that there was an influence of the midwife's competence (knowledge, attitude and skills) on the handling of obstetric emergencies in the City of Blitar.

\section{REFERENCES}

Arikunto. (2010). Riset Prosedure: a Practice Approach, Jakarta: Rineka Cipta.

Gibson. (2008). Human Resource Manajement, Four Edition, Erlangga. Jakarta.

Notoatmodjo, \& Soekidjo. (2010). Health Research Methodology. Jakarta: Rineka Cipta.

Sunaryo. (2010). Psichology for Nursing. Jakarta: EGC.

Notoadmojo, \& Soekidjo. (2012). Health Promotuon and Health Behavior. Jakarta: Rineka Cipta.

Nursalam. (2008). Nursing Education Book. Jakarta: Salemba Medika.

Kementerian Kesehatan RI. (2013). Pocket Book for Maternal Health Services in Basic Health Facilities and Referrals. Jakarta: Kemenkes RI.

Cuningham, F., Gary, Norman, F., Gant. et. all. (2010). Williams Obstetric, Twenry-third Edition. Mc Graw-Hill Companies. United States of America.

Indonesian Maternal Neonatal Care Training. (2015). Training Manual on Basic Trauma Cardio Maternal Neonatal Management. Surabaya: IMNCT.

Lumbanraja, S. (2017). Obstetric Emergency. Medan: USU PRESS.

Hutapea, \& Thoha. (2008). Competency Plus, Jakarta: Gramedia Pustaka Utama.

Kepmenkes RI. (2007). Midwife Professional Standard. Pengurus Pusat Ikatan Bidan Indonesia, Jakarta: Kemenkes RI.

Azwar, \& Saifuddin. (2013). Psychological Series of Human Attitudes Theory and Measurement. Yogyakarta: Liberty.

Mochtar, R. (2011). Obstetric Synopsis. Jakarta: EGC.

Wawan, \& Dewi. (2011). Theory and Measurement of Human Knowledge, Attitudes and Behavior. Yogyakarta: Nuha Medika.

Sugiyono. (2010). Quantitative, Qualitative and $R \& D$ Research Methods. Bandung: CV Alfabeta. Kemenkes RI. (2014). Data Center and Information of The Ministry of Health. Jakarta: Kemenkes RI.

Suryani, \& Sri, E. (2011). Midwifery Concept. Jakarta: Nuha Medika.

Sukarni, I., \& Wahyu. (2015). Maternity Nursing Textbook. Jakarta: Nuha Medika.

Prawiryohardjo, S. (2008). Ginecology, 2nd Edition. Jakarta: Pt. Bina Pustaka.

Kemenkes RI. (2016). Health Ministry Data and Information Center. Jakarta: Kemenkes RI. 
Notoatmodjo. (2014). Health Behavio Science. Jakarta: Rineka Cipta.

Widayatun. (2009). Behavior Science. Jakarta: Info Medika.

Martono, \& Nanang. (2012). Quantitative Research Methods: Content Analysis and Secondary Data Analysis, Revised Edition. Jakarta: Rajawali Pers.

Pengurus Pusat Ikatan Bidan Indonesia. (2016). Midwifery Update Reference Book. Jakarta: IBI.

Sastroasmoro, \& Ismail. (2014). Health Research Methods, Revised Edition. Jakarta: Sagung Seto.

Darwis. (2013). Midwifery Methodology. Jakarta: EGC.

Kemenkes RI. (2016). Neonatal Maternal Emergency Care. Jakarta: Kemenkes RI.

Azwar, S. (2000). Human Attitude Theory and Measurement. Yogyakarta: Pustaka Pelajar 